University of Nebraska - Lincoln

DigitalCommons@University of Nebraska - Lincoln

\title{
HYDROLOGIC CONNECTIVITY AND THE CONTRIBUTION OF STREAM HEADWATERS TO ECOLOGICAL INTEGRITY AT REGIONAL SCALES
}

\author{
Mary C. Freeman \\ Catherine M. Pringle \\ C. Rhett Jackson
}

Follow this and additional works at: https://digitalcommons.unl.edu/usgsstaffpub

Part of the Geology Commons, Oceanography and Atmospheric Sciences and Meteorology Commons, Other Earth Sciences Commons, and the Other Environmental Sciences Commons

This Article is brought to you for free and open access by the US Geological Survey at DigitalCommons@University of Nebraska - Lincoln. It has been accepted for inclusion in USGS Staff -- Published Research by an authorized administrator of DigitalCommons@University of Nebraska - Lincoln. 


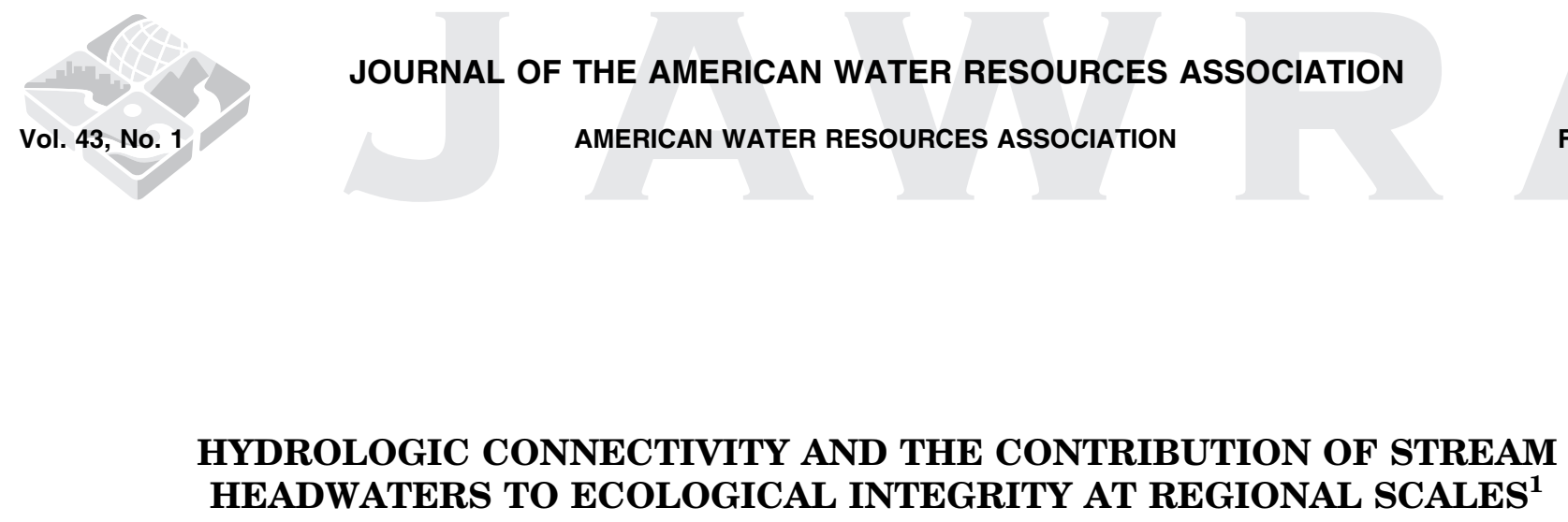

\author{
Mary C. Freeman, Catherine M. Pringle, and C. Rhett Jackson ${ }^{2}$
}

\begin{abstract}
Cumulatively, headwater streams contribute to maintaining hydrologic connectivity and ecosystem integrity at regional scales. Hydrologic connectivity is the water-mediated transport of matter, energy and organisms within or between elements of the hydrologic cycle. Headwater streams compose over two-thirds of total stream length in a typical river drainage and directly connect the upland and riparian landscape to the rest of the stream ecosystem. Altering headwater streams, e.g., by channelization, diversion through pipes, impoundment and burial, modifies fluxes between uplands and downstream river segments and eliminates distinctive habitats. The large-scale ecological effects of altering headwaters are amplified by land uses that alter runoff and nutrient loads to streams, and by widespread dam construction on larger rivers (which frequently leaves free-flowing upstream portions of river systems essential to sustaining aquatic biodiversity). We discuss three examples of large-scale consequences of cumulative headwater alteration. Downstream eutrophication and coastal hypoxia result, in part, from agricultural practices that alter headwaters and wetlands while increasing nutrient runoff. Extensive headwater alteration is also expected to lower secondary productivity of river systems by reducing stream-system length and trophic subsidies to downstream river segments, affecting aquatic communities and terrestrial wildlife that utilize aquatic resources. Reduced viability of freshwater biota may occur with cumulative headwater alteration, including for species that occupy a range of stream sizes but for which headwater streams diversify the network of interconnected populations or enhance survival for particular life stages. Developing a more predictive understanding of ecological patterns that may emerge on regional scales as a result of headwater alterations will require studies focused on components and pathways that connect headwaters to river, coastal and terrestrial ecosystems. Linkages between headwaters and downstream ecosystems cannot be discounted when addressing large-scale issues such as hypoxia in the Gulf of Mexico and global losses of biodiversity.
\end{abstract}

(KEY TERMS: aquatic ecology; rivers/streams; environmental impacts; hydrologic connectivity; biodiversity; ecosystem function.)

Freeman, Mary C., Catherine M. Pringle, and C. Rhett Jackson, 2007. Hydrologic Connectivity and the Contribution of Stream Headwaters to Ecological Integrity at Regional Scales. Journal of the American Water Resources Association (JAWRA) 43(1):5-14. DOI: 10.1111/j.1752-1688.2007.00002.x

\footnotetext{
${ }^{1}$ Paper No. J06011 of the Journal of the American Water Resources Association (JAWRA). Received February 1, 2006; accepted October 4, 2006. (c) 2007 American Water Resources Association. No claim to original U.S. government works.

${ }^{2}$ Respectively, Ecologist, U. S. Geological Survey, Patuxent Wildlife Research Center, Athens, Georgia 30602 (address for correspondence: Institute of Ecology, University of Georgia, Athens, Georgia 30602-2202); Professor, Institute of Ecology, University of Georgia, Athens, Georgia 30602; and Associate Professor, Warnell School of Forestry and Natural Resources, University of Georgia, Athens, Georgia 30602 (E-Mail/Freeman: mary_freeman@usgs.gov).
} 


\section{INTRODUCTION}

The hydrologic connectivity of small headwater streams to navigable waters is clear and unambiguous to ecologists. Every important aspect of the river ecosystem, the river geomorphic system, and the river chemical system begins in headwater streams. Other papers in this issue focus on the contribution of headwater streams to stream flow (Winter, this issue), nutrient cycling and watershedscale water quality (Alexander et al., this issue; Triska et al., this issue), regional biodiversity (Meyer et al., this issue), and as providers of organic matter subsidies to downstream reaches (Wipfli et al., this issue). Our purpose is to consider and provide examples of large-scale ecological effects of headwater alteration.

Headwater streams clearly dominate surface water drainage networks. Definitions of headwater streams vary, but if we define headwaters as all first- and second-order streams, then, in aggregate, these streams compose over two-thirds of the total stream length in a river network (Leopold et al., 1964). A first-order stream is an intermittent or perennial stream with no temporary or perennial tributaries, while a second-order stream is created by the confluence of two first-order streams. Every large river is fed by literally hundreds of thousands of small headwater streams (Leopold et al., 1964). First- and second-order streams may be too small for boating and fishing, but they connect upland and riparian systems with river systems.

In this paper, we illustrate mechanisms by which the cumulative alteration of headwater streams is likely to affect ecological function at larger scales. We begin by defining hydrologic connectivity, considering the need for the legal definition of "connected" to be based on scientific measurements of water, energy, material, and organism transport between waterbodies. We then cite an example of unanticipated, large-scale environmental changes resulting from human impacts on hydrologic connectivity. We follow by considering large-scale consequences of headwater stream alteration. Using examples of coastal eutrophication, diminished riverine productivity, and lowered viability of river biota, we suggest that headwater alteration has the potential to reduce ecological integrity at large spatial scales, particularly where river systems are already affected by landscape changes and downstream modifications including dams, levees and flow regulation. We close by discussing specific research needed to improve our ability to understand and predict the large-scale consequences of altering headwater streams.

\section{HYDROLOGIC CONNECTIVITY: DEFINITIONS AND THE IMPORTANCE OF CONSIDERING LARGE-SCALE EFFECTS OF ALTERATION}

Longitudinal connections within riverine ecosystems have long been recognized by both aquatic and terrestrial ecologists, as illustrated by the widespread use of the term river corridor in the literature. The term connectivity did not emerge in the freshwater literature until the early 1990s (but see Amoros and Roux, 1988). A review of 20 major journals in freshwater ecology and management from 1945-2003 indicates that connectivity surpassed the use of corridor by the late $1990 \mathrm{~s}$, with the trend continuing into the 2000s (Pringle, 2006). In contrast, the term connectivity was widely used a decade earlier in journals in the fields of landscape ecology and conservation biology (e.g., Merriam, 1984). Connectivity is also a fundamental concept of metapopulation ecology (Moilanen and Hanski, 2001). A metapopulation is a group of individual populations that are connected by migration and dispersal. Metapopulation models were initially designed and tested on terrestrial biota (typically insects and small mammals); metapopulation theory has more recently been applied to riverine biota, such as fishes and mussels (Stoeckel et al., 1997; Policansky and Magnuson, 1998; Gotelli and Taylor, 1999; Fagan, 2002).

Freshwater ecologists frequently use the term connectivity to describe spatial linkages within rivers (Stanford and Ward, 1992, 1993; Ward, 1997; Amoros and Bornette, 1999; Wiens, 2002). Ward (1997) defines riverine connectivity as energy transfer across the riverine landscape. Ward and Stanford (1989a) define rivers as having interactive pathways along one temporal dimension (time scales) and three spatial dimensions [i.e., longitudinal (upstream-downstream); lateral (channel-bank/floodplain); and vertical (atmospherechannel-subsurface)]. Consideration of dynamic interactions along these four dimensions has proven to be an effective conceptual framework to understand human impacts on river ecosystems (e.g., Ward and Stanford, 1989b; Boon et al., 1992; Pringle, 1997, 2000; Tockner and Stanford, 2002).

In contrast to riverine connectivity, hydrologic connectivity (Pringle, 2001, 2003a,b) encompasses broader hydrologic connections, beyond the watershed, on regional and global scales. Hydrologic connectivity refers to the water-mediated transport of matter, energy, and organisms within or between elements of the hydrologic cycle (sensu Pringle, 2001), in essence combining the hydrologic cycle with riverine connectivity. Aspects of hydrologic connectivity are essential to maintaining the ecological integrity of ecosystems, where ecological integrity is defined as 
the undiminished ability of an ecosystem to continue its natural path of evolution, its normal transition over time, and its successional recovery from perturbations (Westra et al., 2000). Conversely, hydrologic connectivity also directs and facilitates the flow of exotic species, human-derived nutrients, and toxic wastes in the landscape. Hydrologic connectivity at large scales is a formidable concept because of the inherent complexity of water movement within and between the atmosphere, surface-subsurface systems and the ocean (e.g., Winter et al., 1998); and the extent and magnitude of human alterations (e.g., Pringle and Triska, 2000).

Scientific concepts of connectivity differ from legal definitions. Hydrologists view connectivity as a continuum because the entire landscape is hydrologically connected (Figure 1). Moreover, biological connections among waterbodies are not restricted to pathways of water flow; e.g., migratory birds, amphibians, and winged aquatic insects travel across watershed boundaries. Legally, however, stream navigability and the influence of headwaters on the integrity of interstate waters have played prominent roles in legal questions over Federal jurisdiction of small streams and wetlands. The interstate commerce clause of the U.S. Constitution gives the Federal government authority to regulate river-based commerce, which includes regulating water quality. In the past, the concept of connectivity extended Federal jurisdiction to small streams and isolated wetlands by virtue of their direct hydrologic (regardless of form and rate) and biological linkages to interstate or navigable waters (Downing et al., 2003). Given the complexity of hydrologic connections, it is essential that political and legal determinations of thresholds of connectivity (for purposes of Clean Water Act jurisdiction) be informed by scientific understanding of headwater stream effects on ecological functions at larger scales.

A compelling example of how important it is to consider the large-scale effects of altered hydrologic connectivity concerns alterations in the biogeochemical transport and cycling of silica as a result of the cumulative effects of dams. Rivers supply over $80 \%$ of the total silicate input to oceans (Treguer et al., 1995). Silicate stimulates production of diatoms, which fuel food webs and play a critical role in $\mathrm{CO}_{2}$ uptake (Smetacek, 1998). Increasing evidence links dam construction to decreased silicate transport and alterations in coastal food web structure (Conley et al., 2000). Moreover, reduced riverine inputs of

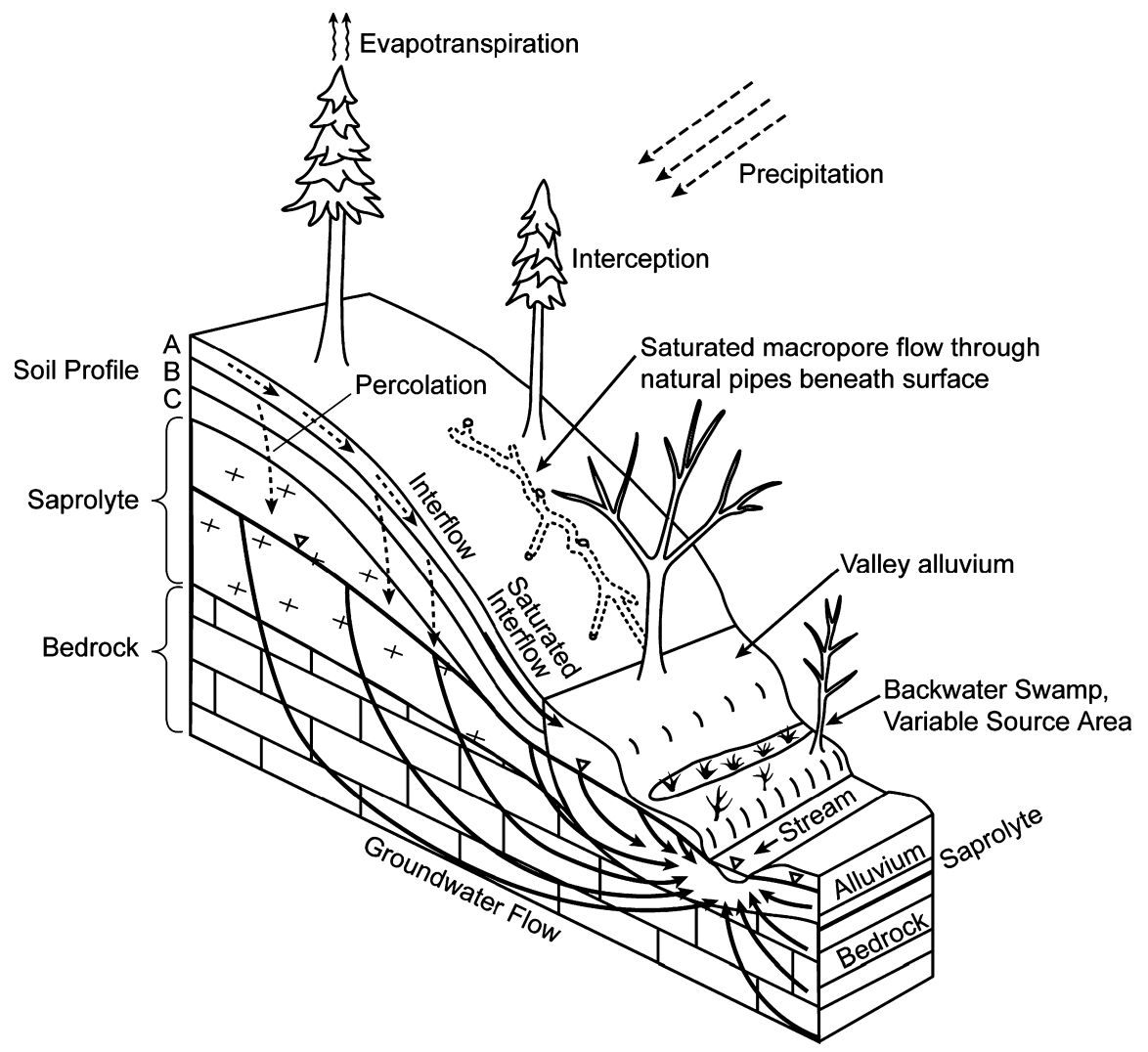

FIGURE 1. The Hydrologic Pathways Connecting the Landscape to Streams and Rivers. When soils are undisturbed by grading, compaction, and paving, most rainfall reaches streams and wetlands by subsurface pathways. Streams and wetlands can be considered the low parts of the landscape into which ground water leaks from the uplands. Ground-water levels rise and fall in response to recharge from infiltrated rainfall and leakage to streams and wetlands. Redrawn from Jackson (in press). 
other elements such as iron, may have far-reaching effects beyond coastal ecosystems (Hutchins and Bruland, 1998). Iron availability has been linked to patterns of silicate uptake. Therefore, reductions of riverine-transported iron (as a result of hydrological alterations) might also affect silicate uptake in nutrient-rich upwelling zones far from the coasts (Ittekkot et al., 2000). Further declines in the delivery of sediments, dissolved silicate, and other elements to estuaries and coastal oceans can be expected as new dams are constructed, with consequences to coastal food webs and wildlife.

Environmental effects of altered nutrient transport in regulated rivers have emerged within the last two decades. This and other examples (e.g., mobilization of methylmercury in reservoirs) suggest that the current extent and magnitude of hydrologic alterations and pollutant loading will result in new, perhaps unexpected, environmental problems, and raise questions of the larger scale effects of other alterations in hydrologic connectivity (Pringle, 2003c).

\section{REGIONAL ECOSYSTEM RESPONSE TO HEADWATER STREAM ALTERATION}

Channelization, diversion through pipes ("piping"), impoundment and burial of headwater streams unavoidably impact stream systems by altering runoff patterns, fluxes to downstream segments, and by eliminating distinctive habitats. Managers and regulators require information on the size and extent of these effects, and also on how increasing cumulative headwater alteration may affect ecosystem integrity, locally and at larger scales. Headwater alteration affects ecological function at larger scales through the loss of unique functions and in relation to the importance of headwater connectivity to downstream and upland systems. We discuss three examples of realized or potential large-scale consequences of headwater loss and alteration. Each of these examples, coastal eutrophication, lowered riverine productivity, and reduced viability of riverine biota, reflect the predominance and position of headwater streams as riverine capillaries into the upland landscape.

Additionally, hydrologic alteration of headwater streams is generally accompanied by water quality impacts. Human activities commonly associated with headwater stream modification include land development, road construction, mining, agricultural drainage, and reservoir creation. Each activity entails significant water quality changes beyond those caused by the physical alteration of the headwater channels. Stream piping to create additional space for buildings, roads, or parking lots is accompanied by elevated streamflow, nutrients, pesticides, fecal coliforms, and pharmaceuticals that are associated with pavement, compacted soils, landscape management, domestic animal waste, and sewer leaks (Paul and Meyer, 2001). Strip mining and hilltop mining excavate some headwater streams and bury others in mine tailings. The downstream receiving waters are affected not only by the loss of the streams, but potentially by acidic ground water and streamflow created by the exposure of an enormous combined surface area of unweathered rock and the resulting oxidation of sulfides and pyrites. Stream systems altered by ditching to improve drainage from agricultural fields also receive high nutrient and sediment concentrations because of fertilizer or manure application and soil erosion. Small streams are often impounded to create "farm ponds," or increasingly, to create "amenities" in residential developments; in both cases, the downstream drainage is influenced not only by replacement of the stream ecosystem with a reservoir but also by nutrient and sediment runoff from the landscape.

Finally, most U.S. (and other Holarctic) river systems are hydrologically altered by dams (Dynesius and Nilsson, 1994), an important fact for considering the emerging consequences of headwater disturbance. In effect, river systems are being squeezed from both ends - downstream by dams and levees that fragment mainstems and isolate channels from their floodplains, and upstream by disturbance and loss of headwater streams. The free-flowing, mid-sized river segments caught between downstream dams and impoundments and upstream headwater disturbance are frequently essential to sustaining aquatic biodiversity (see, e.g. Freeman et al., 2005).

It is thus important to evaluate the ecological effects of headwater stream alteration with respect to additional water quality changes associated with stream disturbance and in the context of downstream channel modifications. Toward this end, we provide examples that illustrate a range of ecosystem effects associated with headwater alteration. Specifically, we examine linkages between headwater modification and: (1) coastal eutrophication and hypoxia, (2) diminished secondary productivity in rivers, and (3) reduced viability of stream biota.

\section{Coastal Eutrophication/Hypoxia}

Loss of nutrient processing in headwaters (Meyer and Wallace, 2001; Triska et al., this issue), accompanied by increased nutrient runoff with landscape disturbance, can cause downstream nutrient loading and contribute to coastal eutrophication and hypoxia. 
Accelerated algal growth and subsequent oxygen depletion in estuaries is a worldwide problem (Turner and Rabalais, 1994; Diaz and Rosenberg, 1995; Justic et al., 1995). Over the last 30 years, the worldwide number of oxygen-starved, coastal dead zones has tripled, primarily because of anthropogenic eutrophication and related hydrological modifications (Malakoff, 1998).

Alteration of headwater ephemeral areas, wetlands, and streams for agricultural purposes in the midwestern U.S. has significantly contributed to the seasonal occurrence of a large-scale $\left(12,000-20,000 \mathrm{~km}^{2}\right)$ recurring area of hypoxia (dissolved oxygen contents $<2 \mathrm{mg} \mathrm{L}^{-1}$ ) in the Gulf of Mexico (Rabalais et al., 1996). Over 20 million hectares of farmland in Ohio, Indiana, Illinois, Iowa, southern Wisconsin, and southern Minnesota was tile-drained from 1870-1920 and 1945-1980 for row-crop agriculture (Zucker and Brown, 1998; Goolsby et al., 2001; Mitsch et al., 2001). Tiles efficiently drain water from the soil saturated zones to streams, thereby reducing residence time in areas conducive to denitrification (saturated sediments of headwater streams and wetlands). In association with chemical fertilizer inputs, tile drainage increases nitrogen export from midwestern croplands (Baker and Johnson, 1981; Fenelon and Moore, 1998; David and Gentry, 2000; McIsaac and Hu, 2004). Nitrate nitrogen loads from the Mississippi River basin to the Gulf of Mexico approximately tripled between 1970 and 2000, with most of the increase occurring before 1983 (Goolsby et al., 2001).

The relatively recent seasonal occurrence of a hypoxia zone in the Gulf of Mexico suggests an ecological threshold response for nitrogen inputs. Nitrogen concentrations had already increased substantially by 1960 without creating large-scale hypoxia, but additional tile drainage and chemical fertilizer application (which increased substantially after 1960; Mitsch et al., 2001) may have tipped the scale. Economic and social costs associated with the zone of hypoxia in the Gulf of Mexico include reduced food resources for fish and shrimp (Rabalais et al., 1995), reduced abundances of fish and shrimp (Pavela et al., 1983; Leming and Stuntz, 1984; Renaud, 1986), declining shrimp catch efficiency (Zimmerman and Nance, 2001), and consequent negative impacts on recreational and commercial fisheries. Restoring the integrity of the system will require widespread land management changes and structural solutions applied to headwaters across the basin (Mitsch et al., 2001).

\section{Diminished Secondary Productivity of River Systems}

Productivity, particularly in forested landscapes, generally increases along the river continuum from headwaters to larger rivers. However, the large aggregate length of headwater streams means that, even though local production may be relatively low, headwaters may still contribute a substantial proportion of total system productivity. For example, total macroinvertebrate production per unit length of stream may increase by 1,000 times from first- to seventh-order streams along a longitudinal gradient in a southern Appalachian River (Grubaugh et al., 1997). However, because of their large cumulative lengths, the smaller streams (i.e., drainage area $<10 \mathrm{~km}^{2}$ ) still contribute at least $10 \%$ of the total macroinvertebrate production in this system (Figure 2). This calculation underestimates the proportion of total production contributed by headwaters because at least half of the network comprises streams draining less than $0.1 \mathrm{~km}^{2}$ (Hansen, 2001), for which production estimates are unavailable. Also, secondary production estimates for the seventh-order sites in this example are among the highest ever measured (Grubaugh et al., 1997) and are driven by production in shallow, rocky, vegetated habitats that are limited to a portion of the total length of larger channels (e.g., about $33 \%$ in the upper Conasauga River, also in the southern Appalachian Highlands; Argentina, 2006). Production in deeper habitats with finer bed sediments may be substantially lower than in bedrock

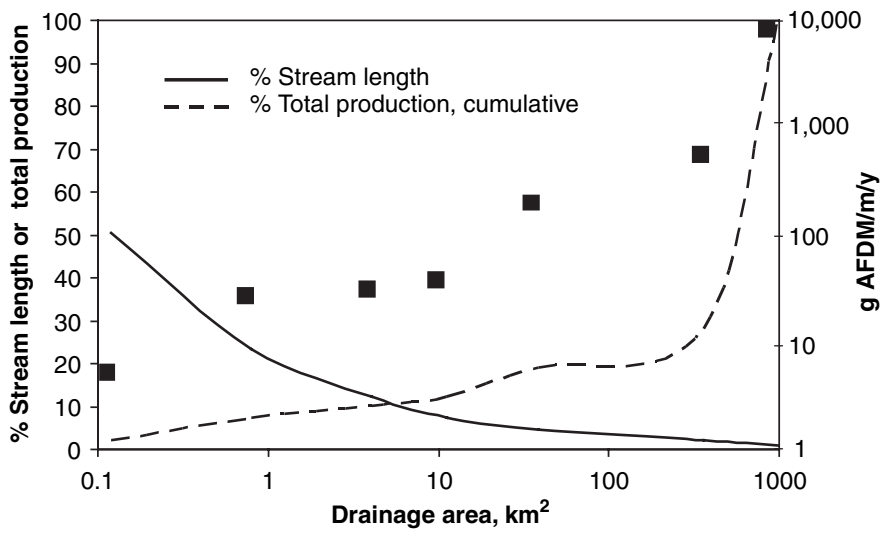

FIGURE 2. An Example of Headwater Contribution to NetworkWide Production by Aquatic Macroinvertebrates. Cumulative percent total secondary production as a function of stream size (broken line) is estimated as a product of annual production (g ash free dry mass per $\mathrm{m}$ stream length, black squares; note logarithmic scale) for first through seventh-order stream sites in the Little Tennessee River basin, NC (Grubaugh et al., 1997), and percent total stream length in orders with corresponding drainage areas (solid line; from Hansen, 2001). Production estimates from Grubaugh et al. were weighted by stream widths and averaged across sites within orders (including sites S3 and M1, and M1 and M2 for third- and fourth-orders, respectively). Percent total stream length for each order was calculated from Hansen's (2001) data for second through seventh-order streams (i.e., excluding the smallest size class of streams, $0.0026-0.062 \mathrm{~km}^{2}$ ), to correspond to the range of drainage areas for which Grubaugh et al. reported production. 
and cobble habitats of larger rivers; for comparison, invertebrate production on submerged woody debris in rivers may be 3-4 times that in sand and mud substrates (Benke et al., 1984). Adjusting the production estimates for the seventh-order sites downward to account for contributions from less productive largerchannel habitats would further increase the relative contribution of low-order streams.

Headwater stream productivity also contributes to production in downstream river segments. Because headwater channels compose most of the length in a river system, these small streams are primary collectors, and processors, of terrestrially derived organic matter. Organic detritus and invertebrates exported from headwaters can substantially subsidize food resources for downstream aquatic communities. The exceptionally high production recorded in seventhorder Appalachian stream sites discussed earlier are driven by filtering invertebrates feeding primarily on transported detritus (Grubaugh et al., 1997; RosiMarshall and Wallace, 2002). Invertebrate production may also support productive (Randall et al., 1995) and species-rich native fish assemblages. In the southeastern U.S., for example, fish assemblages in middle-order rivers comprise numerous small-bodied species feeding on benthic and also on drifting invertebrates. Drift includes terrestrial invertebrates that fall from riparian habitats into streams and that may be consumed by a variety of fishes, in some cases accounting for $50 \%$ or more of fish diets (Nakano and Murakami, 2001; Baxter et al., 2005). Terrestrial subsidies also contribute to production of economically important, drift-feeding fishes such as salmonids (Wipfli and Gregovich, 2002; Cummins and Wilzbach, 2005).

The importance of headwater streams to the trophic basis for downstream assemblages has not been quantified. We and others (Cummins and Wilzbach, 2005; Wipfli, 2005) hypothesize that headwater streams contribute significantly to downstream productivity. The importance of headwater exports is likely accentuated where small streams feed rivers in which local secondary production is depressed by effects of flow alteration (e.g., by upstream dams that cause extreme flow fluctuations or limit floodplain inundation), sediment loading from landscape disturbance (current or historic; Waters, 1995) and loss of migratory fauna because of downstream dams (Freeman et al., 2003).

Finally, river systems, including headwater streams, also subsidize terrestrial foodwebs. Aquatic insect emergence from rivers provides prey for multiple terrestrial consumers (reviewed by Baxter et al., 2005), including, e.g., migratory birds (Nakano and Murakami, 2001). Terrestrial consumers of fishes, including birds and mammals, also clearly utilize aquatic productivity. Loss of productive capacity in headwater streams, especially where small stream corridors represent least-altered portions of landscapes, and of headwater contributions to downstream productivity could cascade into large-scale declines in populations of terrestrial vertebrate and invertebrate predators.

\section{Reduced Viability of Freshwater Biota}

Loss of flora and fauna that typically inhabit headwaters, or that depend on small streams to complete life-cycles, represents large and direct effects of headwater disturbance (Meyer and Wallace, 2001; Meyer et al., this issue). Loss of small-stream species would also reduce basin or region-wide diversity of some taxonomic groups. For example, at least $20 \%$ of the stonefly (Plecoptera) species in eastern North America exclusively inhabit first- and second-order streams (based on species counts from Meyer et al. this issue), and Stark, http://www.mc.edu/campus/users/stark/ stonefly.html; accessed January 2006). Among the 99 described salamander species native to the southeastern U.S., 33 inhabit "small streams" and 33 live adjacent to small, woodland streams (Dodd, 1997). Therefore, $66 \%$ of southeastern U.S. salamander species may be threatened by headwater disturbance. Alteration of small headwater streams in the Alabama River system (which drains portions of 4 physiographic provinces in three U.S. states) could result in the regional loss of as much as 7\% (12 of 184) of fish species native to the system (based on habitat preferences listed in Etnier, 1997), whereas failure to protect habitat in somewhat larger streams (i.e., 'creeks' in Etnier's classification) could threaten $45 \%$ of the drainage's 184 native fishes (Freeman et al., 2005).

In addition to providing habitat, headwater connectivity to downstream segments affects viability of species that occupy, but are not restricted to, headwaters. For example, the Cherokee darter (Etheostoma scotti), is a federally-protected fish that inhabits streams draining between about 0.5 and $100 \mathrm{~km}^{2}$ in a single southeastern U.S. river system (B. Freeman, University of Georgia, personal communication). Fauna such as the Cherokee darter that inhabit dendritic networks of tributary streams have greater potential for dispersal among populations than when populations are arrayed linearly along a stream, and thus have longer expected times to metapopulation extinction (Fagan, 2002). Truncating headwaters from stream systems will in fact have the effect of making networks progressively more linear, with potential effects on species persistence even though their habitat in larger streams may be 
protected by federal regulations. Additionally, imperiled species that only occupy larger streams may also have reduced viability if these species or their prey (e.g., benthic macroinvertebrates) depend on trophic subsidies supplied by headwaters. Failure to protect headwater integrity while believing that downstream habitat protection is sufficient for conservation could substantially underestimate regional loss of biodiversity.

Several anadromous and catadromous fishes utilize the entire stream system, from small headwater streams to estuaries (and the ocean) across their life cycles. For examples, coho salmon (Oncorhynchus kisutch) and steelhead trout (Oncorhynchus mykiss) are two economically and socially important anadromous species for which small headwater streams provide important spawning and rearing habitat. Coho and steelhead reside in rivers entering the Pacific from Central California to Alaska to the Kamchatka Peninsula in Russia, and during their ocean life they live in the Gulf of Alaska and the Bering Sea. Some populations of these species migrate thousands of kilometers upstream to their headwater spawning grounds (Northcote and Hinch, 2004), and they have been observed spawning in as little as 7-10 $\mathrm{cm}$ of water depth (Gribanov, 1948; Briggs, 1953). Coho females frequently choose streams less than $1 \mathrm{~m}$ wide for spawning (Burner, 1951). After the fry emerge, they frequently rear in small streams, with water depths and velocities less than $15 \mathrm{~cm}$ and $15 \mathrm{~cm} / \mathrm{s}$ (Everest and Chapman, 1972), and they prefer streams with abundant cover including overhanging vegetation, undercut banks, submerged vegetation, and woody debris (Bjornn and Reiser, 1991). As the fish grow, they move downstream into progressively deeper and faster habitats (Sandercock, 1991).

Maintenance of intact headwater streams that are accessible to fishes improves the resilience of salmon populations to disturbance. One of the many factors limiting coho and steelhead productivity are small road crossings for which the culverts do not allow upstream fish passage and thus constrict the available useful habitat. Northcote and Hinch (2004) found that stream crossings were "perhaps the greatest environmental impact of forestry on fish migration." In British Columbia alone, there are 225,000 stream crossings with approximately 10,000 new crossings added each year (Harper and Quigley, 2000). By restricting access to headwater streams, fish passage barriers at road crossings force spawning females to select less optimal spawning sites and crowd fry and juveniles into downstream habitats where they are more susceptible to predation.

Urbanization imposes multiple stressors on salmon (larger and more frequent peak flows, habitat simplification, increased concentrations of toxins) and has severe deleterious effects on salmon populations. By altering flow pathways of precipitation to headwater streams (Figure 1), such as when infiltration rates are reduced by soil compaction or paving, urbanization can elevate local stormflows by $2-5$ times, causing rapid channel erosion and biotic simplification (Wolman and Schick, 1967; Hollis, 1975; Booth and Jackson, 1997; Booth et al., 2002). However, the effects of urbanization on salmonids may depend on the spatial pattern of development and stream disturbance. For example, relatively healthy salmonid populations in streams in the vicinity of Seattle, WA, occur only in streams with intact headwaters (Fresh and Lucchetti, 2000). Minimizing disturbance to headwater streams may increase the ecological resilience of these stream systems.

\section{CONCLUSIONS AND RESEARCH NEEDS}

A large-scale perspective is clearly important for informing jurisdiction, management and conservation decisions regarding activities that alter headwater streams. Cumulative effects of human activities (e.g., urbanization, mountain-top mining, intensive agriculture) may have negative consequences on regional and even global scales with respect to societally important issues such as potable water quality, economically important fisheries, and aquatic and terrestrial biodiversity. The contribution of headwater stream alteration to larger scale environmental problems, including coastal eutrophication and regional declines in water quality, fisheries and biodiversity is exacerbated by other human actions that increase nutrient loading to river systems and that diminish ecological functions in lower river reaches.

Research is needed to quantify the large-scale consequences of disturbing or removing (e.g., through piping, impoundment, filling) headwater streams from the river network. Severing the "capillaries" of the system can alter downstream hydrology, water quality, biota and geomorphic processes. Key research questions include: (1) How do cumulative effects of headwater loss and degradation interact with altered hydrologic connectivity and contaminant loading in lower watersheds to modify the transport of contaminants and essential nutrients? (2) At what point do cumulative effects of headwater degradation become so great as to alter ecosystem function, e.g., secondary productivity and population viability, in downstream systems or in adjacent uplands?

The lack of baseline data limits our ability to evaluate changes in riverine productivity or in riverine and riparian consumer communities that may 
Freeman, Pringle, and Jackson

have already occurred in response to altered patterns of nutrient and organic matter transport from headwaters. We suggest that developing a more predictive understanding of what types of ecological patterns may emerge on regional scales as a result of headwater alterations will require comparative field studies (e.g., of systems differing in degree of headwater modification) focused on components and pathways that connect headwaters to river, coastal and terrestrial ecosystems. Even in the absence of these larger scale studies, we cannot discount the linkages between headwaters and downstream ecosystems when addressing large-scale issues such as hypoxia in the Gulf of Mexico and global losses of biodiversity.

\section{ACKNOWLEDGMENTS}

Tracie Nadeau, Mark Rains, Ken M. Fritz, and two anonymous referees provided guidance and numerous helpful suggestions for this manuscript.

\section{LITERATURE CITED}

Alexander, R.B., E.W. Boyer, R.A. Smith, G.E. Schwartz, and R.B. Moore, 2007. The Role of Headwater Streams in Downstream Water Quality. Journal of the American Water Resources Association 43. DOI: 10.1111/j.1752-1688.2007.00005.x.

Amoros, C. and G. Bornette, 1999. Antagonistic and Cumulative Effects of Connectivity: a Predictive Model Based on Aquatic Vegetation in Riverine Wetlands. Large Rivers 11:311-327.

Amoros, C. and A.L. Roux, 1988. Interaction Between Water Bodies Within the Floodplain of Large Rivers: Function and Development of Connectivity. Munstersche Geographische Arbeiten 29:125-130.

Argentina, J.E., 2006. Podostemum ceratophyllum and Patterns of Fish Occurrence and Richness in a Southern Appalachian River. MS Thesis, University of Georgia, Athens, Georgia, 110 pp.

Baker, J.L. and H.P. Johnson, 1981. Nitrate Nitrogen in Tile Drainage as Affected by Fertilization. Journal of Environmental Quality 10:519-522.

Baxter, C.V., K.D. Fausch, and W.C. Saunders, 2005. Tangled Webs: Reciprocal Flows of Invertebrate Prey Link Streams and Riparian Zones. Freshwater Biology 50:201-220.

Benke, A.C., T.C. Van Arsdall, Jr, and D.M. Gillespie, 1984. Invertebrate Productivity in an Subtropical River: The Importance of Habitat and Life History. Ecological Monographs 54:25-63.

Bjornn, T.C. and D.W. Reiser, 1991. Habitat Requirements of Salmonids in Streams. In: Influences of Forest and Rangeland Management on Salmonid Fishes and Their Habitats, W.R. Meehan (Editor). American Fisheries Society Special Publication 19, Bethesda, MD, pp. 83-138.

Boon, P.J., P. Callow, and G.E. Petts, (Editors), 1992. River Conservation and Management. John Wiley, Chichester, UK.

Booth, D.R. and C.R. Jackson, 1997. Urbanization of Aquatic ystems: Degradation Thresholds, Stormwater Detection, and the Limits of Mitigation. Journal of the American Water Resources Association 33:1077-1090.

Booth, D.R., D. Hartley and R. Jackson, 2002. Forest Cover, Impervious-Surface Area, and the Mitigation of Stormwater Impacts.
Journal of the American Water Resources Association 38:835845.

Briggs, J.C., 1953. The Behavior and Reproduction of Salmonid Fishes in a Small Coastal Stream. California Department of Fish and Game Fish Bulletin 94. 62pp p.

Burner, C.J., 1951. Characteristics of Spawning Nests of Columbia River Salmon. U.S. Fish and Wildlife Service Fishery Bulletin 61:97-110.

Conley, D.J., P. Stalnacke, H. Pitkanen, and A. Wilander, 2000. The Transport and Retention of Dissolved Silicate by Rivers in Sweden and Finland. Limnology and Oceanography 45:1850-1853.

Cummins, K.W. and M.A. Wilzbach, 2005. The Inadequacy of the Fish-Bearing Criterion for Stream Management. Aquatic Sciences 67:486-491.

David, M.B. and L.E. Gentry, 2000. Anthropogenic Inputs of Nitrogen and Phosphorus and Riverine Export for Illinois, USA. Journal of Environmental Quality 28:25-34.

Diaz, R.J. and R. Rosenberg, 1995. Marine Benthic Hypoxia; A Review of its Ecological Effects and the Behavioural Responses of Benthic Macrofauna. Oceanography and Marine Biology, Annual Review 33:245-303.

Dodd, C.K., Jr, 1997. Imperiled Amphibians: A Historical Perspective. In: Aquatic Fauna in Peril: The Southeastern Perspective, G.W. Benz, and D.E. Collins (Editors). Southeast Aquatic Research Institute Special Publication 1. Lenz Design and Communications, Decatur, Georgia, pp. 165-200.

Downing, D.M., C. Winer, and L.D. Wood, 2003. Navigating Through Clean Water Act Jurisdiction: A Legal Review. Wetlands 23:475-493.

Dynesius, M. and C. Nilsson, 1994. Fragmentation and Flow Regulation of River Systems in the Northern Third of the World. Science 266:753-762.

Etnier, D.A., 1997. Jeopardized Southeastern Freshwater Fishes: A Search for Causes. In: Aquatic Fauna In Peril: The Southeastern Perspective, G.W. Benz and D.E. Collins (Editors). Southeast Aquatic Research Institute Special Publication 1. Lenz Design and Communications, Decatur, Georgia, pp. 87-104.

Everest, F.E. and D.W. Chapman, 1972. Habitat Selection and Spatial Interaction of Juvenile Chinook Salmon and Steelhead Trout in Two Idaho Streams. Journal of the Fisheries Research Board of Canada 29:91-100.

Fagan, W.F., 2002. Connectivity, Fragmentation, and Extinction Risk in Dendritic Metapopulations. Ecology 83:3243-3249.

Fenelon, J.M. and R.C. Moore, 1998. Transport of Agrichemicals to Ground and Surface Water in a Small Indiana Watershed. Journal of Environmental Quality 27:884-894.

Freeman, M.C., C.M. Pringle, E.A. Greathouse, and B.J. Freeman, 2003. Ecosystem-Level Consequences of Migratory Faunal Depletion Caused by Dams. In: Biodiversity and Conservation of Shads Worldwide, K.E. Limburg and J.R. Waldman (Editors). American Fisheries Society Symposium 35, Bethesda, Maryland, pp. 255-266.

Freeman, M.C., E.R. Irwin, N.M. Burkhead, B.J. Freeman, and H.L. Bart Jr, 2005. Status and Conservation of the Fish Fauna of the Alabama River System. In: Historical Changes in Large River Fish Assemblages of the Americas, J.N. Rinne, R.M. Hughes, and R. Calamusso (Editors). American Fisheries Society Symposium 45, Bethesda, Maryland, pp. 557-585.

Fresh, K.L. and G. Lucchetti, 2000. Protecting and Restoring the Habitats of Anadromous Salmonids in the Lake Washington Watershed, an Urbanizing Ecosystem. In: Sustainable Fisheries Management: Pacific Salmon, E.E. Knudsen, C.R. Steward, D.D. MacDonald, J.E. Williams, and D.W. Reiser (Editors). CRC Press LLC, Boca Raton, Florida, pp. 525-544.

Goolsby, D.A., W.A. Battaglin, B.T. Aulenbach, and R.P. Hooper, 2001. Nitrogen Input to the Gulf of Mexico. Journal of Environmental Quality 30:329-336. 
Gotelli, N.J. and C.M. Taylor, 1999. Testing Metapopulation Models with Stream-Fish Assemblages. Evolutionary Ecology Research 1:835-845.

Gribanov, V.I., 1948. The Coho Salmon (Oncorhynchus kisutch Walb.) - A Biographical Sketch. Izv. Tikhookean. NauchnoIssled. Inst. Rybn. Khoz. Okeanogr. 28:43-101 (Translated from Russian; Fisheries Research Board of Canada Translation Series 370).

Grubaugh, J.W., J.B. Wallace, and E.S. Houston, 1997. Production of Benthic Macroinvertebrate Communities Along a Southern Appalachian River Continuum. Freshwater Biology 37:581-596.

Hansen, W.F., 2001. Identifying Stream Types and Management Implications. Forest Ecology and Management 143:39-46.

Harper, D.J. and J.T. Quigley, 2000. No Net Loss of Fish Habitat: An Audit of Forest Road Crossing of Fish Bearing Streams in British Columbia, 1996-1999. Canadian Technical Report of Fisheries and Aquatic Sciences 2319.

Hollis, G.E., 1975. Effect of Urbanization on Floods of Different Recurrence Interval. Water Resources Research 11:431-435.

Hutchins, D.A. and K.W. Bruland, 1998. Iron-Limited Diatom Growth and Si:N Uptake Ratios in a Coastal Upwelling. Nature 393:561-564.

Ittekkot, V., C. Humborg, and P. Schafer, 2000. Hydrological Alterations and Marine Biogeochemistry: a Silicate Issue? BioScience 50:776-792.

Jackson, C.R., in press. Wetland Hydrology. In: Ecology of Freshwater and Marine Wetlands, D.P. Batzer and R. Sharitz (Editors). University of California Press, Berkeley, CA.

Justic, D., N.N. Rabelais, R.E. Turner, and Q. Dortch, 1995. Changes in Nutrient Structure of River-Dominated Coastal Waters: Stoichiometric Nutrient Balance and its Consequences. Estuarine Coastal Shelf Science 40:339-356.

Leming, T.D. and W.E. Stuntz, 1984. Zones of Coastal Hypoxia Revealed by Satellite Scanning Have Implications for Strategic Fishing. Nature 310:136-138.

Leopold, L.B., M.G. Wolman, and J.P. Miller, 1964. Fluvial Processes in Geomorphology. W.H. Freeman and Company, San Francisco.

Malakoff, D., 1998. Death by Suffocation in the Gulf of Mexico. Science 281:190-192.

McIsaac, G.F. and X. Hu, 2004. Net N Input and Riverine N Export from Illinois Agricultural Watersheds With and Without Extensive Tile Drainage. Biogeochemistry 70:251-271.

Merriam, G., 1984. Connectivity: a Fundamental Ecological Characteristic of Landscape Pattern. Proceedings of the International Association for Landscape Ecology 1:5-15.

Meyer, J.L. and J.B. Wallace, 2001. Lost Linkages and Lotic Ecology: Rediscovering Small Streams. In: Ecology: Achievement and Challenge, M.C. Press, N.J. Huntly, and S. Levin (Editors). Blackwell Science, Oxford, pp. 295-317.

Meyer, J.L., D.L. Strayer, J.B. Wallace, S.L. Eggert, G.S. Helfman, and N.E. Leonard, 2007. The Contribution of Headwater Streams to Biodiversity in River Networks. Journal of the American Water Resources Association 43. DOI: 10.1111/j.17521688.2007.00008.x.

Mitsch, W.J., J.W. Day Jr, J.W. Gilliam, P.M. Groffman, D.L. Hey, G.W. Randall, and N. Wang, 2001. Reducing Nitrogen Loading to the Gulf of Mexico From the Mississippi River Basin: Strategies to Counter a Persistent Ecological Problem. Bioscience 51:373-388.

Moilanen, A. and I. Hanski, 2001. On the Use of Connectivity Measures in Spatial Ecology. Oikos 95:147-151.

Nakano, S. and M. Murakami, 2001. Reciprocal Subsidies: Dynamic Interdependence Between Terrestrial and Aquatic Food Webs. Proceedings of the National Academy of Sciences USA 98:166170.

Northcote, T.G. and S.G. Hinch, 2004. Fish Migration and Passage in Watersheds. In: Fishes and Forestry: Worldwide Watershed
Interactions and Management, T.G. Northcote, and G.F. Hartman (Editors). Blackwell Science, Oxford, pp. 123-142.

Paul, M.J. and J.L. Meyer, 2001. Streams in the Urban Landscape. Annual Review of Ecology and Systematics 32:333-365.

Pavela, J.S. and J.L. Ross, 1983. Sharp Reductions in Abundance of Fishes and Benthic Macroinvertebrates in the Gulf of Mexico off Texas Associated with Hypoxia. Northeast Gulf Science 6:167-173.

Policansky, D. and J.J. Magnuson, 1998. Genetics, Metapopulations, and Ecosystem Management of Fisheries. Ecological Applications 8:119-123.

Pringle, C.M., 1997. Exploring How Disturbance is Transmitted Upstream: Going Against the Flow. Journal of the North American Benthological Society 16:425-438.

Pringle, C.M., 2000. Threats to U.S. Public Lands from Cumulative Hydrologic Alterations Outside of their Boundaries. Ecological Applications 10:971-989.

Pringle, C.M., 2001. Hydrologic Connectivity and the Management of Biological Reserves: A Global Perspective. Ecological Applications 11:981-998.

Pringle, C.M., 2003a. The Need for a More Predictive Understanding of Hydrologic Connectivity. Aquatic Conservation 13:467471.

Pringle, C.M., 2003b. What is Hydrologic Connectivity and Why is it Ecologically Important? Hydrological Processes 17:2685-2689.

Pringle, C.M., 2003c. Interacting Effects of Altered Hydrology and Contaminant Transport: Emerging Ecological Patterns of Global Concern. In: Achieving Sustainable Freshwater Systems: A Web of Connections, M. Holland, E. Blood, and L. Shaffer (Editors). Island Press, Washington, D.C, pp. 85-107.

Pringle, C.M., 2006. Hydrologic Connectivity: A Neglected Dimension of Conservation Biology. In: Connectivity Conservation, K. Crooks, and M. Sanjayan (Editors). Cambridge University Press, New York, pp. 233-254.

Pringle, C.M. and F.J. Triska, 2000. Emergent Biological Patterns and Surface-Subsurface Interactions at Landscape Scales, Chapter 7. In: Stream and Groundwaters, J.B. Jones and P.J. Mulholland (Editors). Academic Press, San Diego, CA, pp. 167-193.

Rabalais, N.N., F.R. Burditt, L.D. Coen, B.E. Cole, C. Eleuterius, K.L. Heck, T.A. McTigue, S.G. Morgan, H.M. Perry, F.M. Truesdale, R.K. Zimmerfaust, and R.J. Zimmerman, 1995. Settlement of Callinectes sapidus Megalopae on Artificial Collectors in Four Gulf of Mexico Estuaries. Bulletin of Marine Science 57:855-876.

Rabalais, N.N., R.E. Turner, Q. Dortch, W.J. Wiseman Jr, and B.K. Sen Gupta, 1996. Nutrient Changes in the Mississippi River and System Responses on the Adjacent Continental Shelf. Estuaries 19:366-407.

Randall, R.G., J.R.M. Kelso, and C.K. Minns, 1995. Fish Production in Freshwaters: Are Rivers More Productive Than Lakes? Canadian Journal of Fisheries and Aquatic Sciences 52:631-643.

Renaud, M., 1986. Hypoxia in Louisiana Coastal Waters During 1983: Implications for Fisheries. Fishery Bulletin 84:19-26.

Rosi-Marshall, E.J. and J.B. Wallace, 2002. Invertebrate Food Webs Along a Stream Resource Gradient. Freshwater Biology 47:129-141.

Sandercock, F.K., 1991. Life history of Coho Salmon (Oncorhynchus kisutch). In: Pacific Salmon: Life Histories, C. Groot, and L. Margolis (Editors). UBC Press, Vancouver, British Columbia, pp. 395-446.

Smetacek, V., 1998. Diatoms and the Silicate Factor. Nature 391:224-225.

Stanford, J.A. and J.V. Ward, 1992. Management of Aquatic Resources in Large Catchments: Recognizing Interactions Between Ecosystem Connectivity and Environmental Disturbance. In: Watershed Management, R.J. Naiman (Editor). Springer-Verlag, New York, pp. 91-124. 
Freeman, Pringle, and Jackson

Stanford, J.A., and J.V. Ward, 1993. An Ecosystem Perspective of Alluvial Rivers: Connectivity and the Hyporheic Corridor. Journal of the North American Benthological Society 12:48-60.

Stoeckel, J.A., D.W. Schneider, L.A. Soeken, K.D. Blodgett, and R.E. Sparks, 1997. Larval Dynamics of a Riverine Metapopulation: Implications for Zebra Mussel Recruitment, Dispersal, and Control in a Large-River System. Journal of the North American Benthological Society 16:586-601.

Tockner, K. and J.A. Stanford, 2002. Riverine Flood Plains; Present State and Future Trends. Environmental Conservation 29:308330.

Treguer, P., D.M. Nelson, A.J. van Bennekom, D.J. DeMaster, A. Leynart and B. Queguiner, 1995. The Silica Balance in the World Ocean: A Re-Estimate. Science 268:375-379.

Triska, F.J., J.H. Duff, R.W. Sheibley, A.P. Jackman, and R.J. Avanzino, 2007. DIN Retention-Transport through Four Hydrologically Connected Zones in a Headwater Catchment of the Upper Mississippi River. Journal of the American Water Resources Association 43, DOI: 10.1111/j.1752-1688.2007. 00006.x.

Turner, R.E. and N.N. Rabalais, 1994. Coastal Eutrophication Near the Mississippi River Delta. Nature 368:619-621.

Ward, J.V., 1997. An Expansive Perspective of Riverine Landscapes: Pattern and Process Across Scales. River Ecosystems 6:52-60.

Ward, J.V. and J.A. Stanford, 1989a. The Four-Dimensional Nature of Lotic Ecosystems. Journal of the North American Benthological Society 8:2-8.

Ward, J.V., and J.A. Stanford, 1989b. Riverine Ecosystems: The Influence of Man on Catchment Dynamics and Fish Ecology. In: Proceedings of the International Large River Symposium, D.P. Dodge (Editor). Canadian Special Publication in Fisheries and Aquatic Sciences 106:56-64.

Waters, T.F., 1995. Sediment in Streams: Sources, Biological Effects and Control. American Fisheries Society Monograph 7, Bethesda, MD, $251 \mathrm{pp}$.

Westra, L., P. Mioller, J.R. Karr, W.E. Rees and R.E. Ulanowicz, 2000. Ecological Integrity: Integrating Environmental Conservation and Health. In: Ecological Integrity and the aims of the Global Integrity Project, D. Pimentel, L. Westra, and R.F. Noss (Editors). Island Press, Washington, D.C, pp. 19-44.

Wiens, J.A., 2002. Riverine Landscapes: Taking Landscape Ecology into the Water. Freshwater Biology 47:501-515.

Winter, T.C., 2007. The Role of Ground Water in Generating Streamflow in Headwater Areas and in Maintaining Baseflow. Journal of the American Water Resources Association 43. DOI: 10.1111/j.1752-1688.2007.00003.x.

Winter, T.C., J.W. Harvey, O. Lehn Franke and W.M. Alley, 1998. Ground Water and Surface Water: A Single Resource. U.S. Geological Survey Circular (USA) 1139.

Wipfli, M.S., 2005. Trophic Linkages Between Headwater Forests and Downstream Fish Habitats: Implications for Forest and Fish Management. Landscape and Urban Planning 72:205213.

Wipfli, M.S. and D.P. Gregovich, 2002. Export of Invertebrates and Detritus from Fishless Headwater Streams in Southeastern Alaska: Implications for Downstream Salmonid Production. Freshwater Biology 47:957-969.

Wipfli, M.S., J.S. Richardson, and R.J. Naiman, 2007. Ecological Linkages Between Headwaters and Downstream Ecosystems: Transport of Organic Matter, Invertbrates, and Wood Down Headwater Channels. Journal of the American Water Resources Association 43. DOI: 10.1111/j.1752-1688.2007.00007.x.

Wolman, M.G. and A.P. Schick, 1967. Effects of Construction on Fluvial Sediment in Urban and Suburban Areas of Maryland. Water Resources Research 3:451-464.
Zimmerman, R.J. and J.M. Nance, 2001. Effects of Hypoxia on the Shrimp Fishery of Louisiana and Texas. Coastal and Estuarine Sciences 58:293-310.

Zucker, L.A. and L.C. Brown, , 1998. Agricultural Drainage: Water Quality Impacts and Subsurface Drainage Studies in the Midwest. Ohio State University Extension Bulletin 871. 